\title{
ACRL Board of Directors' actions, June 1998
}

\section{Highlights of the Board's Annual Conference meetings}

D uring the 1998 ALA Annual Conference in Washington, D.C., the ACRL Board of Directors took the following actions:

\section{ACRL governance}

Confirmed electronic and conference call votes taken between February and May 1998: February 10, 1998, second vote to adopt revised bylaws; May 18, 1998, to expand the ACRL Legislative Agenda to include: preservation, digitization, funding to support the National Agricultural Library, funding for the National Endowment for the Humanities, and library appropriations; and to establish the Millennium Task Force.

By consent, voted to approve a name change for ACRL's Constitution and Bylaws Committee to ACRL Bylaws Committee and to establish three discussion groups: Sports and Recreation, Team-based Organizations, and Criminal Justice/Criminology.

Accepted the final report from the ACRL/Chapters Task Force and ap-

\section{Memorial Resolution for Mario Casalini}

ACRL and ALCTS Boards approved the following resolution:

WHEREAS Mario Casalini, owner and director of Casalini Libri, the premier jobber of Italian books and journals and provider of bibliographic information about said publications, died on May 20, 1998, after a valiant struggle with cancer; and

WHEREAS he was a strong and long-time supporter of the American Library Association, who rarely missed a Midwinter Meeting or Annual Conference; and

WHEREAS he was renowned for his grace and stamina in the exhibit booth, and also was instrumental in the creation of the international aisle in the Conference Exhibit Hall; and

WHEREAS he was known for extending his hospitality to groups of international librarians visiting Florence as well as those who were attending conferences where he was exhibiting; and
WHEREAS he was supportive of interlibrary cooperative efforts in and around Florence and beyond, working with the Library of Congress and bibliographic utilities, and also helped to develop and sustain a system of cooperative cataloging and communications to serve libraries; therefore,

BE IT RESOLVED that the members of the American Library Association join his loved ones in mourning Mario Casalini; and therefore

BE IT FURTHER RESOLVED that the members of the American Library Association recognize we will miss his resolute. dedicated, visionary leadership as well as his friendship and good counsel.

Ed. note: A copy of this resolution was read at the memorial service for Mario Casalini on Monclay, June 29, 1998, at the Library of Congress. Copies of the resolution were transmitted to the Casalini family and to Casalini Libri in Florence, Italy. 


\section{Outcomes assessment task force} recommendations and resolution

The ACRL Board approved these recommendations and resolution:

1. ACRL Board adopt an explicit policy of endorsing the development and use of outcomes assessment among academic libraries.

2. ACRL foster continued cooperation with the regional and specialized accrediting agencies.

3. The ACRL Board charge the ACRL Stanclards and Accreditation Committee to develop "Standards for ACRL Standards," which require the standards-writing committees to follow similar formats and approaches in their efforts.

\section{Resolution}

WHEREAS the ACRL strategic plan emphasizes the importance of our association influencing the larger higher education environment, and

WHEREAS organizations prominent in that environment, such as accrediting agencies, higher education associations, and state boards of higher education have adopted the assessment of educational outcomes as their principal indicator of achievement and quality, and

WHEREAS cooperative projects between ACRL and such agencies show promise of producing new avenues for improving our libraties' support and status on their campuses, and

WHEREAS such projects would be furthered by ACRL's policies and practices becoming congruent with national assessment trends,

NOW THERFFORE, BE IT RESOIVED that ACRL adopt the following policy:

The Association of College and Research Libraries recognizes the assessment of outcomes as an integral means of determining the adequacy and quality of libraries and their programs. The association directs its constituent bodies to incorporate this concept intos their various activities and policies, including the drafting of ACRL standards and guidelines.

Ed. note: The full report is available on the Web at http://www.ala org/acrl/ outcome.html.

proved the task force recommendations (see sidebar on p. 585).

\section{Approved, upon recommendation from} the ACRL Government Relations Committee, a job description for ACRL legislative representatives with the proviso that some wordsmithing be done and brought to the Board's attention when completed.
Expanded the past-president's duties to include planning for, convening, and maintaining a record of the ACRL Fellows activities.

Requested that the Bylaws Committee review the current staggering of the terms of office of Board members, and recommend a method for returning to the staggering of terms prescribed in the $\mathrm{By}$ laws.

\section{ACRL appointments}

Approved the names of three ACRL members: Barbara Jones, Laurence Miller, and James Schmidt as nominees to the ALA Intellectual Freedom Committee for the Honor Roll, celebrating the 30th anniversary of the Office of Intellectual Freedom. These members were nominated because they had made significant contributions in sustaining intellectual freedom efforts in their communities.

\section{Approved, upon recommendation from} the Education and Behavioral Sciences Section (EBSS), forwarding Laurene Zaporozhetz's name to the ALA Executive Board as one of its representatives to the NCATE Board of Examiners.

\section{Approved, upon recommendation from} various ACRL sections and the ACRL International Relations Committee, the following IFLA Section Standing Committee nominees: Section of Art Libraries, Nancy L. Stokes; Section on Bibliography, Talbot Huey; Section on Rare Books and Manuscripts, Susan Allen; Section of Science and Technology Libraries, Julia Gelfand; and Section of University Libraries and Other Research Libraries, Barbara Ford.

\section{ACRL structure}

Approved establishing a Friends of ACRL group to be officially launched in January 1, 1999.

\section{Awards and honors}

By consent, approved a memorial resolution to Mario Casalini (see sidebar on p. 582).

Approved a resolution from the Academic or Research Librarian of the Year 


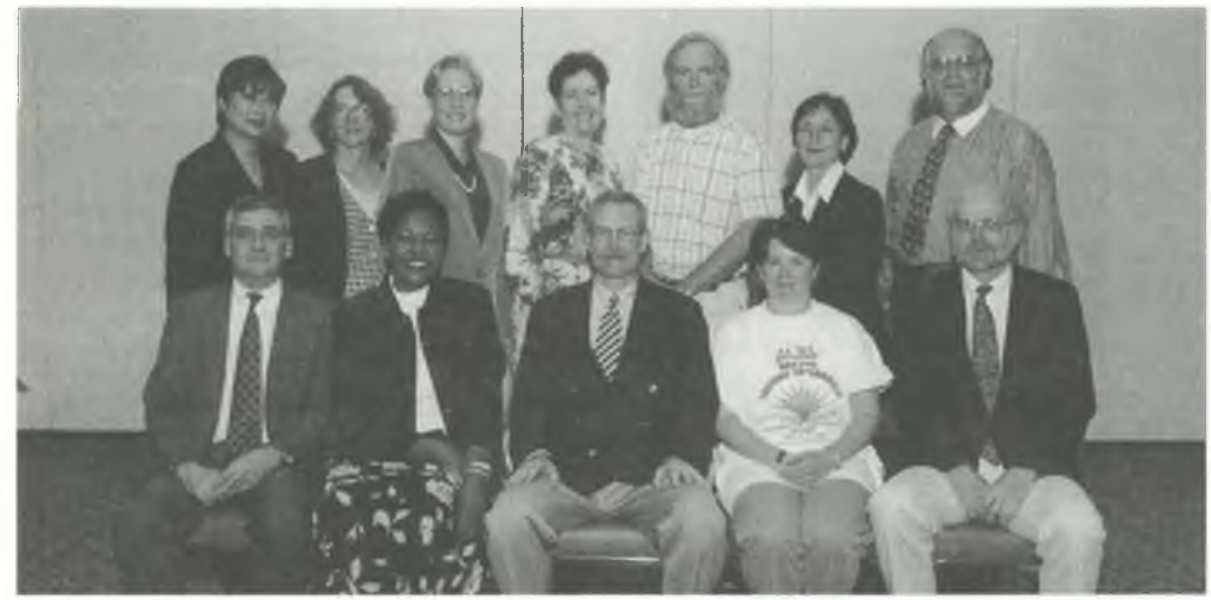

ACRL Board 1997-98 (I to r): (backrow) Linda Muroi, Carol Pfeiffer, Helen Spalding, Jill Fatzer, John Sheridan, Victoria Montavon, Bernard Fradkin; (front row) William Miller, Althea Jenkins, W. Lee Hisle, Maureen Sullivan, and Ray English.

\section{Academic or Research Librarian of the Year Award Resolution}

WHEREAS, the Association of College and Research Libraries has for twenty years been privileged to present the Academic or Research Librarian of the Year Award to recognize individuals who have made outstanding contributions to the field of academic librarianship; and

WHEREAS, the Association has been enabled to present the Academic or Research Librarian of the Year Award through the generous financial support and encouragement of Baker \& Taylor Books; and

WHEREAS, the Academic or Research Librarian of the Year Award is presented annually in recognition of a record of accomplishment and contribution to the profession through scholarly research, and positively influencing the practice as well as the evolution and improvement of academic librarianship generally,

THFREFORE, be it resolved, that the Board of Directors of the Association of College and Research Libraries commemorate the twentieth anniversary of the presentation of the Academic or Research Librarian of the Year Award by adopting this resolution commending the foresight and wisdom of former members of this Board in developing and presenting said award; and

BE IT FURTHER RESOLVEI), that the Board of Directors bring to the artention of the members of the Association the names of all of those who have been recipients of this Award since its institution, the names of whom the Secretary of the Association is directed to attach to and publish with all copies and publications made of this Resolution; and

BE IT FURTHER RESOLVED, that the Board commends, and expresses its sincere appreciation to Baker \& Taylor Books for its constant and generous financial support and sponsorship of this Academic or Research Librarian of the Year Award over the twenty years in which the award has been presented, as well as for its long-term dedication to and support of the profession of academic librarianship; and

DISPOSITION OF THE RESOLUTION: COPies of this Resolution shall be sent to each living recipient of the Academic or Research Librarian of the Year Award and to Baker \& Taylor Books, and that this Resolution be published in College E Research Library News.

Below is a list of the Academic or Research Librarian of the Year Award winners.

Previous recipients: Allen B. Veaner (1998), James G. Neal (1997), Ralph Russell (1996), Joseph Boissé (1995), Irene Braden Hoadley (1994), William A. Moffett (1993), Carla Stoffle (1992), Richard De Gennaro (1991), Patricia Battin (1990), John P. McGowan (1989), Edward G. Holley (1988), Duane Webster (1987), Margaret Beckman (1986), Jessie Carney Smith (1985), Richard 1). Johnson (1984), Richard M. Dougherty (1983), William Budington (1982), Beverly P. Lynch (1981), Evan Ira Farber (1980), Henriette D. Avram and Frederick G. Kilgour (1979), Keyes D. Metcalf and Robert D. Downs (1978). 


\section{Bernard Fradkin receives EBSCO Award}

WHEREAS Dr. Bernard Fradkin has been an ACRL Board member from 1994 to 1998 ; and

WHERAS he has been a strong advocate for all academic libraries, including community and junior college libraries and for all personnel in libraries;

BE IT MOVED that the ACRL Board congratulates Dr. Fradkin on his receipt of the 1998 EBSCO Leadership Award

Award Committee recognizing the 20th-year anniversary of the award and Baker and Taylor for its sponsorship (see sidebar on $p$. 584).

Approved the resolution honoring Dr. Joseph A. Boissé on his retirement as a university librarian, an outstanding leader in the Association of College and Research Libraries (ACRL), and an active member of the American Library Association (ALA) and awarding him permanent membership in ACRL (see sidebar on p. 586).

Approved the resolution honoring ACRL Board member Dr. Bernard Fradkin for his service, advocacy for all academic libraries and for all personnel in libraries, and congratulated him on receipt of the 1998 EBSCO Leadership Award (see adjacent sidebar).

\section{Financial actions}

Approved the ACRL balanced budget definition.

Approved the 1998-99 ACRL and CHOICE budgets: ACRL budget revenues of $\$ 2,315,000$, expenses of $\$ 2,142,825$, and a surplus of $\$ 172,176$; CHOICE budget rev-

\section{Chapter Relations Task Force report}

These task force recommendations were ap proved by the ACRL Board:

1. That funding for each ACRL chapter be increased from $\$ 0.75$ to $\$ 1.00$ for each ACRL national member living within the geographic region served by the chapter, and that the small chapter allocation be continued at its current level.

2. That ACRL, beginning in the 1999-2000 fiscal year, provide additional funding to chapters in the amount of $\$ 10$ for each new member of ACRL in the chapter's geographic region who joined in the previous fiscal year, if the chapter conducted ACRL membership recruitment activities and summarized them in its annual report.

3. That, with the exception of the requirement to submit annual reports, ACRL limit restrictions on funds allocated to chapters to those required by ALA policy.

4. That each ACRL affiliate chapter be expected to submit a brief, one page annual report of its activities to the ACRL office by September 1 of each year, including in it a statement of how the chapter's activities supported the ACRL Strategic Plan in regard to the goals of professional development and legislative issues; that the form developed by this task force (and available on the Web) be used by each chapter in submitting its report; that all chapter annual reports be distributed to both the ACRL Chapters Council and the ACRL Board; that both the regular allocation and new member funding be withheld from any chapter that fails to submit an annual report for two consecutive years; and that such funding be reinstated once a chapter has submitted an annual report.

5. That an annual summary and update of the ACRL Strategic Plan be mailed to each ACRI affiliate chapter and the Chapters Council officers.

6. That an annual meeting be held between the Chapters Council officers and representatives of the ACRL Board for the purpose of considering issues of mutual concern.

7. That new chapters either incorporate or belong to a state association that is incorporated within one year of their recognition by ACRL; that existing chapters incorporate or become a part of an incorporated state association by the end of the year 2000; and that ACRL. provide guidance and advice to chapters on the process of incorporation.

8. That chapters be encouraged to offer opportunities, such as discounts on conference registration, to ACRL members who are not members of the chapter.

Ed. note: The full report is on the Web at htp:// www.ala.org/acrl/chapttf.html. 


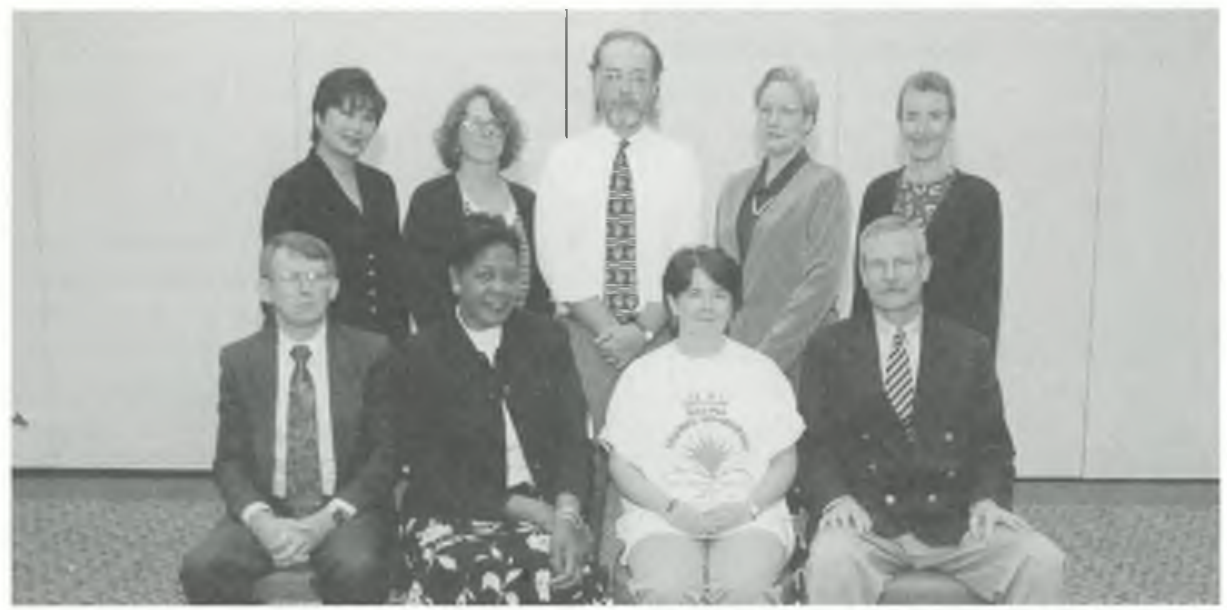

ACRL 1998-99 Board (I to r): (back row) Linda Muroi, Carol Pfeiffer, William E. Brown, Helen Spalding, Mary Lee Sweat; (front row) Larry Hardesty, Althea Jenkins, Maureen Sullivan, and W. Lee Hisle. Not pictured: Barbara Baxter Jenkins, Paul E. Dumont, Dana C. Rooks, and Lynn Sutton.

enues of $\$ 1,931.350$, expenses of $\$ 2,018,777$, and a projected deficit of $(\$ 87,427)$.

\section{Approved ten scholarships at $\mathbf{\$ 9 9 5}$ each} to enable four minority librarians, four librarians who are new to the profession, and two library school stuclents who are ACRL members to participate in the 1999 information literacy immersion program.
Approved adding $\$ 12,000$ to the 199899 ACRL staff salaries line in the budget for upgrading selected positions during the year.

Approved a pilot program for 19992000 of revenue sharing for ACRL Sections that sponsor preconferences during the fiscal year that result in net revenue.

\section{Resolution honoring Joseph A. Boissé on his retirement}

WHEREAS, Dr. Joseph Boissé has recently announced his retirement as University Librarian at the University of California, Santa Barbara, where he has served since 1983; and

WHEREAS, Dr. Boissé has had a distinguished career as a librarian and administrator at Santa Barlara, the University of Wisconsin Parkside, and at Temple University, was responsible for the acquisition of many major collections, the initiation of many innovations in electronic information services, and establishment of the first minority library fellowship in North America; and

WHEREAS, Dr. Boissé has been an outstanding leader in the Association of College and Research Libraries, serving as its President, National Conference Chair, and Chair of the first ACRL Colleagues Committee; and

WHEREAS, Dr. Boissé has also been highly active within the American Library Association overall, serving as a member of Council, chairing the Intellectual Freedom Committee, and holding other important offices; and

WHEREAS, Dr. Boissé was named as ACRL's Academic or Research Librarian of the Year in 1994-95, in recognition of his outstanding contributions to the profession of academic librarianship;

THFREFORE, be it resolved that the Association of College and Research Libraries hereby awards 1)r. Joseph Boissé the status of permanent honorary member, in appreciation of and in recognition of his many contributions to the association and the profession during his clistinguished career, and

BE IT FURTHER RESOLVED that the board and the membership of the association wish Dr. Boissé much good health and happiness during his retirement. 


\section{Higher education}

Confirmed the electronic vote taken on

March 12, 1998, to endorse the American. Council on Education statement, "On the Importance of Diversity in Higher Education."

\section{Professional development}

Confirmed the conference call votes of May 18,1998 , to name Denver as the 2001 National Conference site; and to establish criteria and an application process for 1999 National Conference scholarship program.

Approved the grant proposal from the Institute for Information Literacy to seek funding to support an institute on "Best Practices" in information literacy in order to develop criteria for program modeling throughout the profession.

Approved sponsoring 17 programs in addition to the ACRL President's Program at the 1999 ALA Annual Conference in New Orleans.

\section{Publishing}

Endorsed the ARL Scholarly Publish- ing and Academic Resources Coalition (SPARC) initiative and committed $\$ 5,000$ to support the work. SPARC is a newly formed alliance of libraries that aims to foster expanded competition in scholarly communication (see p. 565 for details)

Approved the recommended policies and procedures for the ACRL Web page defined by the ACRL Web Task Force in its report. (Ed.note: These will be published in the ACRL Guide to Policies and Procedures.)

Approved, upon recommendation of the Publications Committee, to charge future national conference committees to publish each conference's contributed papers so that a permanent record will be established and they will be picked up by appropriate indexing and abstracting services,

\section{Standards}

VOTED to accept the final report from the Academic Libraries Outcomes Assessment Task Force and approved the recommendations in the report (see sidebar on p. 583).

\section{"The Past is Prologue." \\ -Wm. Shakespeare}

These words convey a philosophy long held by Northern Micrographics. It is a philosophy that the tapestry of our past must be preserved, since all learning is based upon past insights.

This preservation takes both the digital and physical form, from CD-ROM to acid-free, reference quality, bound books.
And so we would ask this question of you:

"What do you know that's worsh saving?"

Call us and discover more about how we can further preserve the fabric of past knowledge and future insight.

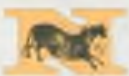

Northern Micrographics, Inc. www.normicro.com 
